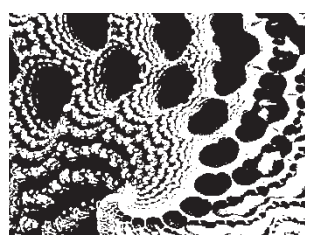

\title{
THE IMPACT OF MIGRATION MOVEMENTS ON INNOVATION ACTIVITIES IN CROATIAN COUNTIES
}

Nebojša STOJČIĆ, Marija BEČIĆ, Perica VOJINIĆ University of Dubrovnik, Dubrovnik

UDK: 338.121(497.5-35):314.15

Izvorni znanstveni rad

Primlieno: 15. 1. 2015.

Innovation activities are one of the most important engines behind economic growth. Among factors that facilitate development of innovations a particularly prominent place belongs to social and cultural diversity of particular geographic areas. Contributions within a number of academic disciplines point to the positive impact of the heterogeneity of the population on the generation of new ideas, knowledge diffusion, entrepreneurship and economic growth. However, the relationship between migration movements and innovations at the regional level has been investigated to a lesser extent. This is especially true when it comes to spatial effects of migration movements on innovations that have not been addressed in the existing literature. The objective of this research is to explore spatial impact of migration movements on innovation activities of Croatian counties in the 2005-2013 period. Results obtained using the spatial panel Durbin econometric technique point to a negative intraregional and positive interregional impact of intercounty and international migration movements on regional innovation activity. Increased innovation activity within individual regions has a positive impact on the same activity of neighbouring regions.

Keywords: immigration, innovation, regional analysis

$\triangle \quad$ Nebojša Stojčić, Department of Economics and Business Economics, University of Dubrovnik, Lapadska obala 7, 20000 Dubrovnik, Croatia. E-mail: nstojcic@unidu.hr 
For centuries, migration movements have been recognised as an important engine behind the creation of new ideas. Evidence from medieval Europe from Italy to United Kingdom point to the beneficiary impact of foreign craftsmen and artisans on the development of local industries (David, 1993). More recent movement of scientists and engineers, due to the increasing globalisation of economic activity and removal of administrative borders, has paved the way for a new generation of research on the migration-innovation relationship and the role of immigrations in regional and national development. Within economics, New Economic Geography models, backed up with a substantial amount of empirical research, suggest that migrants and innovation activity tend to be spatially clustered in dense agglomerated areas. At the same time, research on creativity within both economics and sociology has implied that immigration encourages innovation by challenging the traditional way of thinking and increasing the creative potential of host countries and regions (Feldman \& Florida, 1994; Kerr, 2009).

The need to understand drivers of innovations arises from their importance for economic growth. Over recent years several theoretical models under the umbrella of the endogenous growth theory have been put forward explaining the ability of firms and industries to differentiate themselves from rivals on the global market and appropriate above average returns through development of new products and services (Schumpeter, 1942; Romer, 1990; Aghion \& Howitt, 1992). As competitiveness of firms and industries is at the foundations of national growth prospects, it follows that innovations hold the key to the ability of nations and regions to grow and to provide their citizens with a better standard of living. However, despite the widely recognised importance of innovations, surprisingly little research has been conducted on the relationship between migration movements and innovations. This is particularly true when one considers the spatial effects of migration movements and innovation that, to the best of our knowledge, have not been addressed in empirical literature. Our research seeks to fill this gap in the literature.

The objective of this paper is to examine the relationship between migration movements and innovation in Croatian counties over the 2005-2013 period. To this end, research raises several questions previously unaddressed in the literature. First, what is the impact of innovation activity in particular regions on the same activity of other regions? Second, are there any differences in the impact of international and interregional migration movements on innovation activities of 
DRUŠ. ISTRAŽ. ZAGREB GOD. 25 (2016), BR. 3 STR. 291-307

STOJČIĆ, N., BEČIĆ, M., VOJINIĆ, P.:

THE IMPACT OF..
Croatian regions? Third, what are the differences between intraregional and interregional impacts of migration movements on innovations? The paper is structured as follows. The next section gives an overview of existing research on the impact of migration movements on innovations. Patterns of migration and innovation in Croatian counties are analysed in section three. The fourth section provides an explanation of the methodology and results of the model relating regional migration patterns and their innovation activities. Section five concludes.

\section{THEORETICAL FRAMEWORK}

Traditional economic theory postulates that in the long run all economic entities should converge to the steady state rate of growth and any growth disparities should diminish (Solow, 1956). However, evidence from many countries and regions point to the persistence of growth disparities. Building on these foundations over recent decades, several theoretical models have been put forward offering alternative explanations of ability of nations to grow. Grouped under the heading of endogenous growth theory, these models suggest that the ability of nations (and regions) to specialise themselves in the production of knowledge and technology intensive products offers higher prospects for growth (Romer, 1986, 1990; Aghion \& Howitt, 1992; Grossmann \& Helpman, 1994; Aghion \& Howitt, 1998). The underlying logic behind such reasoning is that innovations provide their owners with the ability to differentiate from their rivals and to accrue above-average return on their activities. These predictions have been supported by a substantial amount of empirical literature.

While a number of factors and forces that facilitate the conceptualization, development and market success of new products and services have been identified in existing literature, little attention has been given to the role of migration movements. There are several channels through which migratory movements may facilitate the generation of innovations (Ozgen, Nijkamp, \& Poot, 2011). On the one hand, changes in the size, density and structure of population increase the variety and quantity of demanded products (Mazzolari \& Neumark, 2009). These changes lead to the growth of firms, creation of new start-ups and implementation of new technologies, all of which may encourage innovations (Freeman \& Soete, 1997). On the other hand, the mobility of workers leads to changes in the skill composition (Poot, Waldorf, \& Wissen, 2008). According to Hunt and Gauthier-Loiselle (2008), immigration may boost innovative activities directly through contributions of immigrants to the research and indirectly through spillovers on colleague researchers. Ottaviano and 
DRUŠ. ISTRAŽ. ZAGREB GOD. 25 (2016), BR. 3, STR. 291-307

STOJČIĆ, N., BEČIĆ, M., VOJINIĆ, P: THE IMPACT OF..
Peri (2006) also imply that the knowledge and skills of immigrants may be complementary to the knowledge and skills of local workers.

In addition to the above-mentioned economic reasons for the existence of relationship between migration movements and innovations, it has been recognised that the creation of new ideas and knowledge as well as their diffusion in specific geographic areas is enhanced by the concentration of people with different socio-cultural backgrounds. Fujita and Weber (2004) point out that "knowledge creation" is based on the abilities and skills of people with different social and cultural origin. Immigrants, very often, have access to a set of personal and business networks which are different from those of local residents. The mentioned differences in knowledge and information access offer the opportunity to increase productivity and creativity of local interactions and to encourage knowledge spillovers and innovation (Maré, Fabling, \& Stillman, 2011). From there it follows that cultural diversity encourages innovation and creativity since it entails knowledge and skill variety (Alesina \& La Ferrera, 2005).

An important feature of innovations is their spatial concentration. According to New Economic Geography, the diffusion of economic activity including knowledge and technology spillovers is spatially concentrated (Krugman, 1991). Feldman and Florida (1994) suggest that innovations tend to cluster geographically depending on an area's technical infrastructure. Authors note that the capacity to innovate arises from the interaction between many economic elements: existing firms, research and development sectors, a network of institutions, natural resources and the concentration of human capital (talents, knowledge and skills of the population). This usually happens in areas where R\&D-oriented firms or universities are established. They also observe that the concentration of such specialized resources, through knowledge spillovers and other externalities, reinforces a region's capacity to innovate and to grow. In addition, Kerr (2009) found that ethnic inventors tend to cluster in metropolitan areas and, in that way, contribute to an increasing spatial concentration of innovation activities.

The above predictions are consistent with propositions of theoretical models of channels for the diffusion of knowledge and technology. To this end, it is suggested that ideas spread across the market through horizontal channels such as demonstration, market competition and worker mobility among rival companies as well as through the vertical linkages such as training and transfer of skills to backward firms (suppliers) and forward ones (distributors and buyers). As these effects have a localised nature, it follows that the innovation activity will be spatially concentrated. This is the cause of the 
DRUŠ. ISTRAŽ. ZAGREB GOD. 25 (2016), BR. 3, STR. 291-307

STOJČIĆ, N., BEČIĆ, M., VOJINIĆ, P.:

THE IMPACT OF.. creation of a high performing "core" and less advanced "peripheral" regions. Overall, it can be maintained that growth prospects of regions depend on their innovation activity, which in turn is influenced with regional patterns of migration. Bearing in mind the spatial concentration of innovation activities, the understanding of these effects has important implications for the reduction of the interregional development gap.

\section{LITERATURE REVIEW}

Despite theoretical predictions about the beneficial impact of migration movements on innovations, empirical literature in this field is scarce and studies are yet starting to emerge. This is particularly true for less advanced economies such as Central and East European countries, where no attempts have been undertaken to address these issues. Evidence from developed countries point to the leading role of immigrants in innovation and job creation processes (Saxenian, 1999; Stephan \& Levin, 2001; Wadhwa, Saxenian, Rissing, \& Gereffi, 2008). More recently, Hunt and Gauthier-Loiselle (2010) suggested that highly-skilled immigrants have a positive impact on the number of patents in the USA. Similarly, Hunt (2009) found out that immigrants who entered on a student/trainee visa or temporary work visa outperform native college graduates in wages, patenting, commercializing and licensing patents. Immigrants who arrived as legal permanent residents perform similarly to natives, while those who arrived as dependents on temporary visas perform worse than the natives. The positive impact of migration movements on innovation has been confirmed in other countries as well (Patridge \& Furtan, 2008; Maré et al., 2011).

Faggian and McCann (2006) point out that the innovativeness of a region encourages university graduates to seek employment in that region. The results of their later study (Faggian \& McCann 2009) indicate that for England and Wales there is a two-way causality between the interregional human-capital employment-migration flows of recent university graduates and the innovation performance of regions. In addition, they find little support that the presence of local universities or small firms promotes regional innovation.

Another line of research examined the impact of migration movements on innovation through increased cultural diversity. Findings from Ozgen et al. (2011) for 170 European regions suggest that a distinct composition of migrants from different backgrounds and the number of migrants contribute to the regional innovativeness. Findings from several studies point to the important role of migrants' education (Niebuhr, 2010; Bratti \& Conti, 2013). On the one hand, cultural diversity among highly qualified employees has a par- 
DRUŠ. ISTRAŽ. ZAGREB GOD. 25 (2016), BR. 3, STR. 291-307

STOJČIĆ, N., BEČIĆ, M. VOJINIĆ, P.

THE IMPACT OF. ticularly strong impact on regional innovation output. On the other hand, the prevalence of low-educated migrants in some regions has been negatively related to the innovation activities. These studies also point out that in an environment characterised by the dominance of low-skilled migrants, the competencies of highly qualified ones are often under-utilised, thus generating an overall negative effect of migration movements on innovations.

Breschi, Lissoni, and Tarasconi (2014) analysed the existing literature on migration and innovation, with special emphasis on empirical studies based on patent and inventor data. Their findings suggest that immigrant inventors in terms of productivity contribute to innovation in the US and selected European countries (such as the Netherlands, Italy and Sweden). A study made by Miguelez and Fink (2013) provides a descriptive overview of inventor migration patterns. Their findings suggest that among the largest receiving countries, the US exhibits by the highest inventor immigration rate, followed by Australia and Canada. European countries lag behind in attracting inventive talent, while Central American, Caribbean and African economies show the largest inventor brain drain, in relation to the number of home country inventors.

While being generally scarce, existing literature on the relationship between innovations and migration movements points to the positive impact of the latter on the former. This is particularly true for the contribution of highly educated migrants in regional innovation activity. However, the weakness of existing literature is the fact that the majority of the existing evidence is observed at the national level covering developed world economies. There has been no attempt to address the role of migration movements on innovation activity of regions in less advanced economies or to explore the spatial patterns of migration and innovation. This research attempts to fill the aforementioned gap in the literature.

\section{IMMIGRATION AND INNOVATION PATTERNS IN CROATIAN COUNTIES}

In order to examine the relationship between regional innovative activity and migration movements, diverse sources of data were combined. The data on migration movements were taken from the Statistical Yearbook of the Republic of Croatia (Croatian Bureau of Statistics). Data on patent applications were taken from the OECD database and data on national accounts were taken from the EUROSTAT database. Our dataset contains information on patent applications, on the interregional migration of population and on international migrations for the period 2005-2013. 
DRUŠ. ISTRAŽ. ZAGREB GOD. 25 (2016), BR. 3 STR. 291-307

STOJČIĆ, N., BEČIĆ, M., VOJINIĆ, P.

THE IMPACT OF.

(1) FIGURE 1

Average number of patent applications in Croatian counties for the period 2005-2013
Patents are among the most widely used measures of innovation output. However, it is prone to weaknesses for which it is often criticized. Kemp, Folkeringa, de Jong, and, Wubben (2003) note that it presents only an intermediate measure of innovation output. Furthermore, in firm level analyses it has been suggested that patents are sensitive to firm and industry characteristics as well as to changes in legislation (Arundel \& Kabla, 1998; Brouwer \& Kleinknecht, 1999). Bearing the above-said in mind, it needs to be noted that information on innovation activities at regional level is relatively difficult to obtain and alternative measures of innovation activity such as proportion of sales coming from new products or processes in context of Croatia and Central and South East European countries do not exist. To this end, the chosen indicator (defined as the share of each region in the country's total number of patent applications) is the best available one.

Figure 1 shows the share of each region in the country's total number of patent applications over the analysed period. It is apparent that over $75 \%$ of all patent applications made in that period have come from the regions where largest Croatian cities are located, City of Zagreb, Split-Dalmatia County and Primorje-Gorski Kotar County.

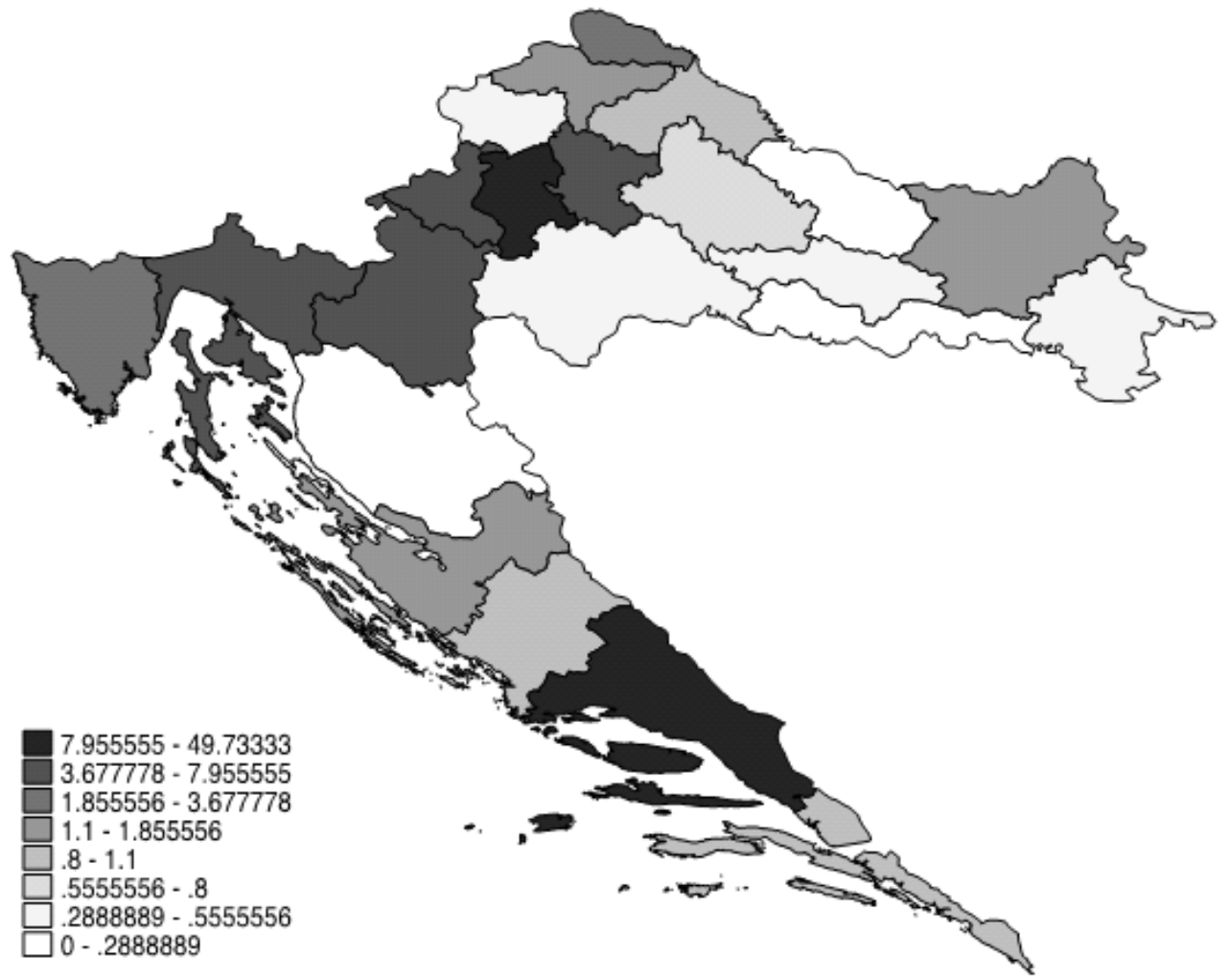

Source of data: OECD patent applications dataset 
DRUŠ. ISTRAŽ. ZAGREB GOD. 25 (2016), BR. 3, STR. 291-307

STOJČIĆ, N., BEČIĆ, M. VOJINIĆ, P.:

THE IMPACT OF..

(1) FIGURE 2A

Migration patterns in

Croatian counties for

the period 2005-2013.

interregional mig-

ration movements

(per 10000 citizens)
Since the major agglomerations and university centres in Croatia are situated in these regions, this finding may be explained as confirmation of the new economic geography predictions, the so-called core-periphery models (Krugman, 1991; Fujita, Krugman, \& Venables, 1999). According to the mentioned model, the concentration of economic activity and population in a certain geographic area leads to the creation of agglomeration externalities such as knowledge spillovers through the vertical and horizontal interaction channels among firms, through the cooperation between firms and scientific research and professional institutes, and through the interaction between firms and customers. Consequently, this has a multiplicative positive effect on knowledge production and innovative activities.

The analysis of migration patterns indicates that the areas characterised by high positive levels of immigration per capita are also the areas with some of the highest numbers of patent applications (Figures 2A, 2B). These findings are valid for both migration between counties, and international migration movements. According to the mentioned discussion about the direct positive effects of migration movements on creativity and also indirect positive effects on innovation activities, these findings address the need for further examination of spatial effects between innovation and migration movements in Croatia.
$89.0674-416.3291$ $54.67383-189.0674$ $-12.30034-54.67383$ $-66.94166-12.30034$ $163.8743-66.94166$ $63.8743-66.94$ $-274.1545--163.8743$ $-374.4024--274.1545$ $-390.7274-374.4024$

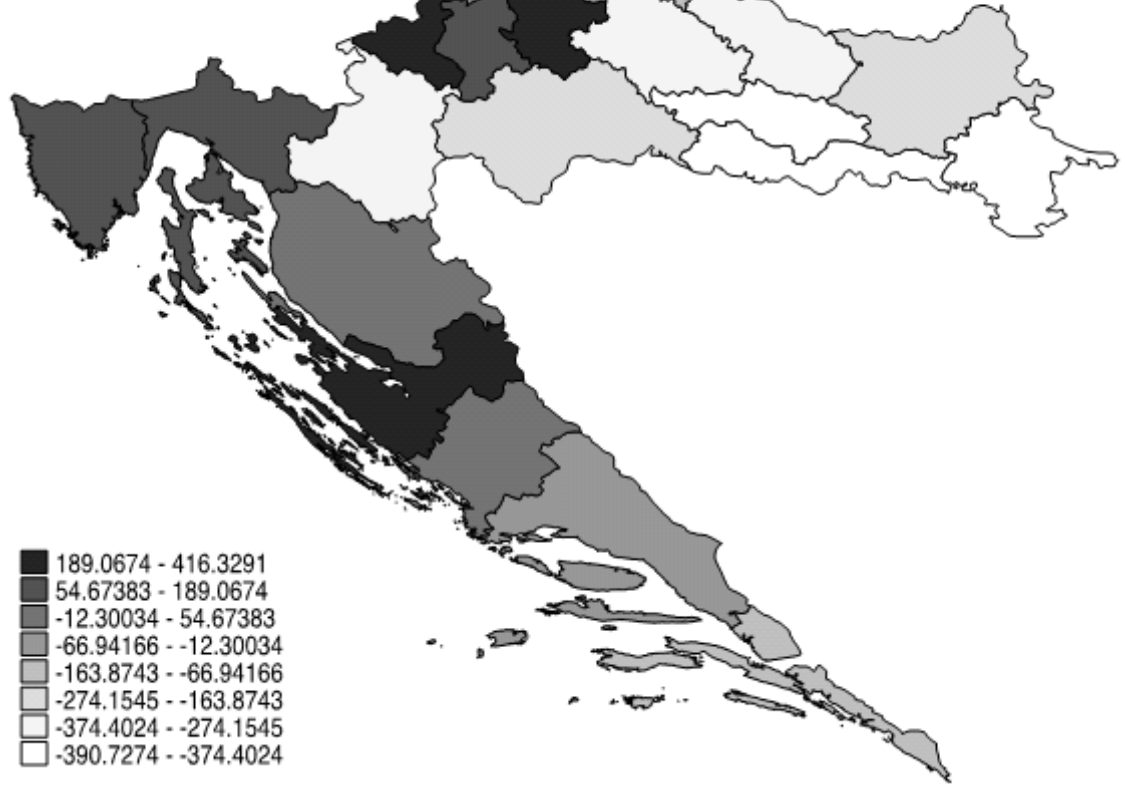

Source of data: Statistical Yearbooks 


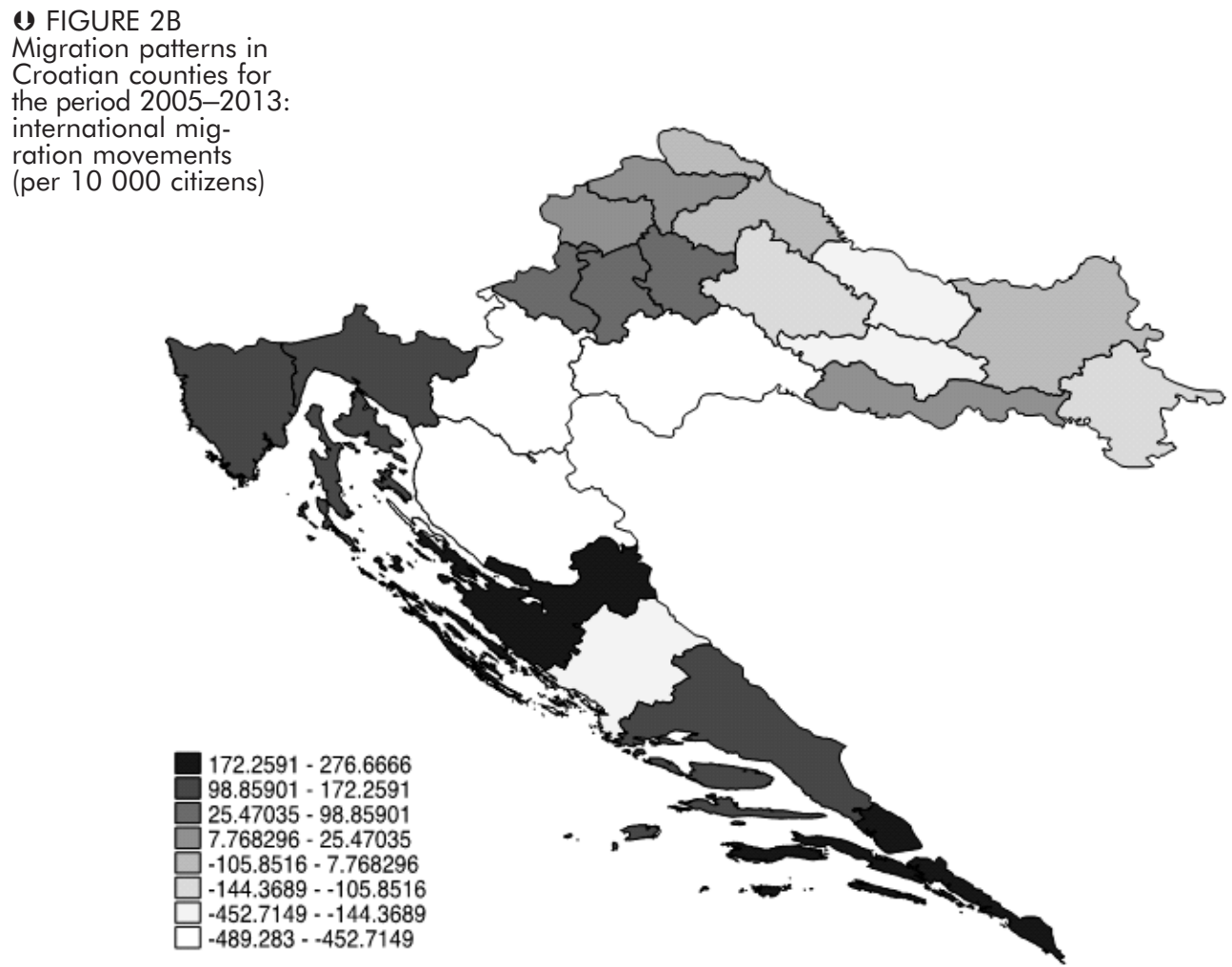

Source of data: Statistical Yearbooks

In order to analyse the spatial effects of innovation activity, Moran's diagram was created (Figure 3).

The $X$-axis represents innovation activity in a certain region, and Y-axis represents its spatial lag (Anselin, 1996).

The vertical axes in Figure 3 represent the average number of patent applications and the average value of spatial lag of the same variable in the observed period at the national level.

The upper part of the diagram reveals a negative correlation between the innovation activity of Croatian regions and their spatial lags. However, it is evident that this finding is driven by the presence of a few outliers. The removal of these regions from the sample (lower part of Figure 3) reveals a positive correlation among other regions.

Accordingly, the impact of the most innovative regions on innovation activities in other regions is negative as predicted by the New Economic Geography while there is evidence of positive spatial correlation among less innovative regions. This finding suggests the existence of a wide gap in terms of innovation activities among Croatian regions. 
DRUŠ. ISTRAŽ. ZAGREB GOD. 25 (2016), BR. 3, STR. 291-307

STOJČIĆ, N., BEČIĆ, M., VOJINIĆ, P.

THE IMPACT OF..

S FIGURE 3

Spatial patterns of patent activity in the period 2005-2013

in Croatian counties

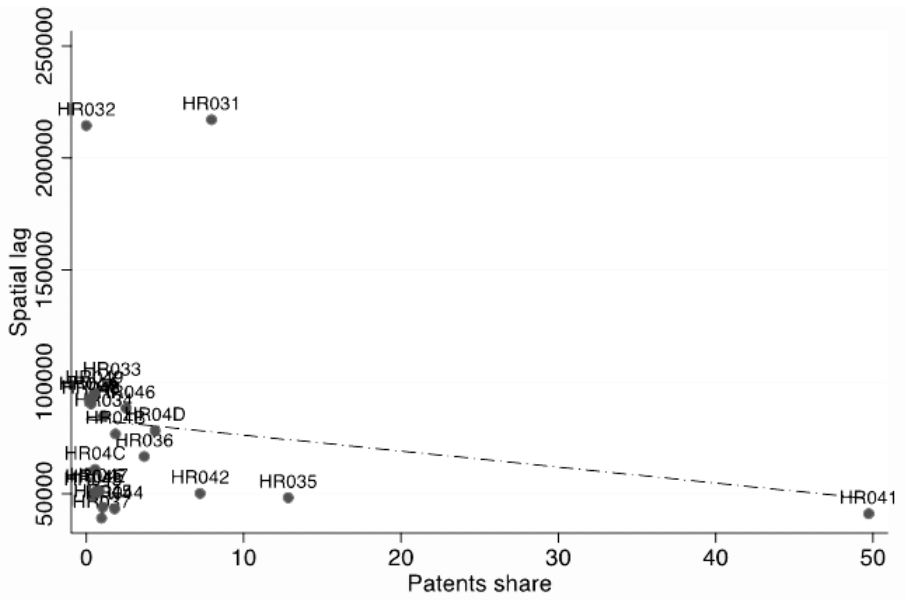

- $\mathrm{AR}(1)$ mpatents Spatial Lag $\quad$-..-.- - Fitted values

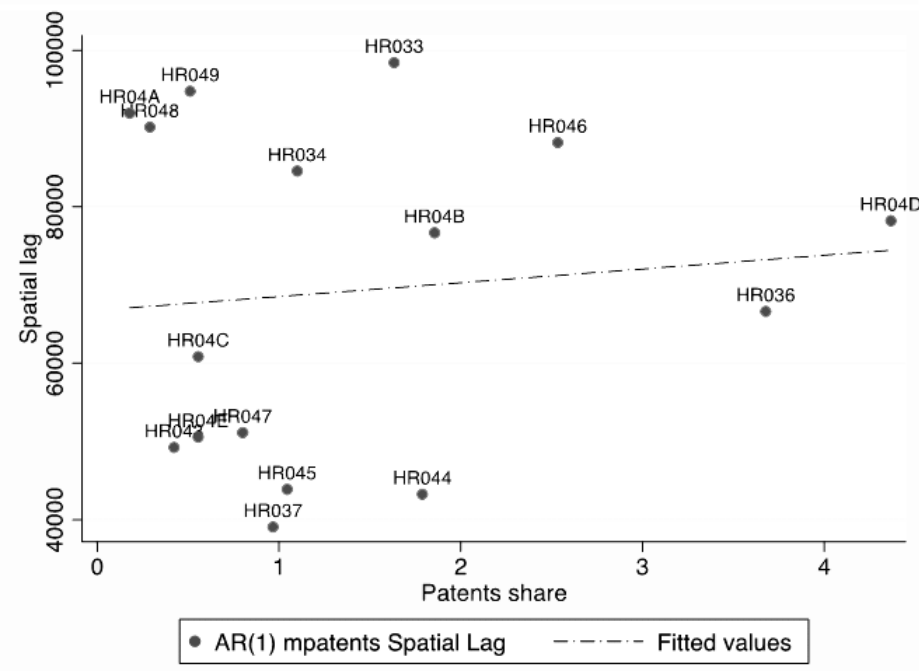

MODEL SPECIFICATION AND DISCUSSION OF FINDINGS

Considering the strong migration trend of the most innovative Croatian regions and taking into account the existing literature on the relationship between migration movements and innovation, the specification of model is as follows:

Innovative output ${ }_{i t}=f\left(\right.$ InterCountry Migr ${ }_{i t}$, International Migr $\left.r_{i t}, G D P_{p c}\right)$

The dependent variable Innovative output is measured by the share of region $i$ in year $t$ in the total number of patent applications in the country. The choice of independent variables is limited by data availability on the county level for a longer pe- 
DRUŠ. ISTRAŽ. ZAGREB GOD. 25 (2016), BR. 3 STR. 291-307

STOJČIĆ, N., BEČIĆ, M., VOJINIĆ, P. THE IMPACT OF.

$\rightarrow$ TABLE Model diagnostics riod of time. The key variables are two measures of migration activity defined as net migration per 100000 residents between counties in a certain year and net migration per 100000 residents between counties and foreign countries in the same year. Existing studies suggest a positive effect of migration movements on innovation activity through mechanisms such as knowledge spillovers, encouraging creativity and cultural diversity. In this context, it is expected that migration has a positive effect on innovation. Apart from the mentioned variables, the level of regional gross domestic product per capita is included in this model as an indicator of the level of regional development. It is expected that more developed regions have better ground for developing innovative activities and, consequently, a positive coefficient for that variable is expected.

Number of observations $\quad 189$

Number of regions

21

Log likelihood function $\quad-359.19$

Wald test

LR TEST SDM vs. OLS $H_{0}:(\rho=0)$

$620.78^{* * *}$

$3.5^{* *}$

LR TEST $H_{0}:\left(w X^{\prime} s=0\right)$

$9.7^{* * *}$

0.002

Acceptable interval for $\rho$

$-0.01<\rho<0.01$

Spatial autocorrelation in error term

$\mathrm{H}_{0}$ : (no spatial autocorrelation)

Global Moran MI

$0.15^{* * *}$

Global Geary GC

$0.82^{* * *}$

$-0.15^{* * *}$

$2.75^{* * *}$

$4.83^{* *}$

Moran MI Error Test

$15.53^{* * *}$

LM Error (Robust)

Spatial lag of dependent variable

$\mathrm{H}_{0}$ : (no spatial autocorrelation)

LM Lag (Anselin)

0.08

Lm Lag (Robust)

$10.77^{* * *}$

General spatial autocorrelation

$\mathrm{H}_{0}$ : (no spatial autocorrelation)

LM SAC (LMErr+LMLag_R)

$15.61^{* * *}$

LM SAC (LMLag+LMErr_R)

$15.61^{* * *}$

${ }^{* *} p<0,01 ;{ }^{* *} p<0,05 ;{ }^{*} p<0,10$

The use of panel dataset as well as the fact that one of the primary objectives of research is to explore the existence of spatial patterns of innovation and migration movements suggests that a suitable estimator should be looked for within the family of spatial econometric techniques. A common approach to the selection of appropriate estimator is based on model 
DRUŠ. ISTRAŽ. ZAGREB GOD. 25 (2016), BR. 3, STR. 291-307

STOJČIĆ, N., BEČIĆ, M. VOJINIĆ, P: "

THE IMPACT OF.. diagnostics such as Lagrange (LM) test for spatial lag of dependent variable, spatial autocorrelation in error term and tests for different forms of spatial correlation such as robust LM, Likelihood ratio or Wald tests (Elhorst, 2013). Model diagnostics are presented in Table 1. Results of the LR test suggest that spatial estimators should be given preference over conventional ones. Also, there is no sufficient evidence to accept the hypothesis that spatial lags of dependent and independent variables are jointly equal to zero. Furthermore, all tests reject the hypothesis about the non-existence of spatial autocorrelation in error term and general spatial autocorrelation. The existence of spatial correlation in the dependent variable is also confirmed with the robust LM test while the conventional test suggests the opposite.

Burridge (1981) notes that in the case of findings such as those in Table 1, the spatial Durbin panel estimator is a suitable econometric technique. Bearing the above-said in mind, the estimator mentioned above, which takes into account the spatial effects of both dependent and independent variables, will be used in the subsequent analysis. Furthermore, due to a low number of cross-sectional units (regions), spatial effects are estimated only for the dependent variable and variables representing migration flows. The model takes the following form:

$$
\begin{aligned}
\text { patents }_{i t}=c_{0} & +\rho \sum_{j=1}^{\mathrm{n}} w_{i j} \text { patents }_{j t}+\beta_{1} \text { InterRegMigr }_{i t}+\beta_{2} \text { IntlMigr }_{i t} \\
& +\beta_{3} \text { GDPpc }_{i t}+\Phi_{1} \sum_{j=1}^{\mathrm{n}}=w_{i j} \text { InterRegMigr }_{j t} \\
& +\Phi_{2} \sum_{j=1}^{\mathrm{n}} w_{i j} \text { IntlMigr }_{j t}+\lambda \sum_{j=1}^{\mathrm{n}} \varepsilon_{j t}+u_{i t}
\end{aligned}
$$

In the above equation, coefficient $\rho$ measures the spatial lag of the dependent variable. The expression $\Sigma_{l=1}^{\mathrm{n}} \mathrm{W}_{i j}$ patents $s_{j t}$ is the interaction effect of the dependent variable with the dependent variables of other units (regions) while $w_{i j}$ is the $i, j-$ th element of a prespecified nonnegative $\mathrm{NxN}$ spatial weights matrix $\mathrm{W}$. The spatial dependence parameter $(\rho)$ measures the impacts of change in the share of patents applied for in other regions (e.g. region $j$ ) on the proportion of patent applications in region $i$.

Variables InterRegMigr and IntlMigr refer to interregional and international net migrations per 100000 residents lagged two periods. The use of lagged instead of contemporaneous levels of these variables is motivated by two reasons. On the one hand, the realisation of effect of migrations does not happen instantaneously but rather takes place over time. On the other hand, Ozgen et al. (2011) note that migration movements are likely to be endogenous as migrants might be attracted to regions where per capita income is growing and where there is considerable innovation activity. Analogously, 
DRUŠ. ISTRAŽ. ZAGREB GOD. 25 (2016), BR. 3 STR. 291-307

STOJČIĆ, N., BEČIĆ, M., VOJINIĆ, P. THE IMPACT OF..

$\rightarrow$ TABLE 2 Results of estimation higher migration to some area can lead to higher innovation activity. To address these issues, the decision was made to use migration variables lagged two periods. Coefficients $\theta$ measure the spatial effects of migration movements in other regions (e.g. region $j$ ) on innovativeness in region $i$ in the peri$\operatorname{od} t$. Coefficient $\lambda$ is the estimated impact of spatial autocorrelation in error term while coefficients $\beta$ present the estimated impact of other independent variables on the dependent one. Finally, $u_{i t}$ is the usual idiosyncratic error term. An important factor in spatial econometric analysis is the choice of spatial weights matrix, a symmetric $\mathrm{NxN}$ matrix that defines the position of units (regions) in space in relation to one another (Le Sage, 1999). The matrix in this paper is inverse distance matrix, defined in the way that each element of matrix $\mathrm{W}_{\mathrm{ij}}$ measures a distance between regional centers (Baltagi, Egger, \& Pfaffermayr, 2007). Following common procedure, each row of matrix is standardized so that the sum of its elements amounts to 1 (Olejnik, 2008).

\begin{tabular}{clc}
\hline Variables & Spatial lag of dependent variable & $0.002^{* *}$ \\
& Interregional migrations & $-0.02^{* * *}$ \\
& International migrations & $-0.01^{* *}$ \\
Interregional migrations - spatial lag & $0.0002^{* *}$ \\
International migrations - spatial lag & $0.0001^{*}$ \\
GDPpc & $0.003^{* * *}$ \\
Constant term & $-20.58^{* * *}$ \\
\hline
\end{tabular}

${ }^{* * *} p<0,01 ;{ }^{* *} p<0,05 ;{ }^{*} p<0,10$

Results of econometric analysis are presented in Table 2. The significant and positive coefficient of spatial lag for the dependent variable suggests the diffusion of the positive influence of innovative activity in certain counties on the same activity in other Croatian regions. The results suggest the existence of a negative within-county effect of both international (between the region and other countries) and interregional (between counties) migration. Such a finding is closer to the studies which suggest that low-educated immigrants have a negative impact on innovation activity.

Both variables that measure spatial lags of migration movements are positive and significant. This finding suggests that the intensity of migration movements in the neighbour counties and immigration movements from abroad into the neighbour counties have a positive impact on innovation activity within certain counties. A potential explanation of this finding is that neighbour regions present a pool of creative ideas whose realisation, due to higher financial capabilities and developed infrastructure, takes place in urban areas. Such a finding can be considered as a recommendation to policy mak- 
DRUŠ. ISTRAŽ. ZAGREB GOD. 25 (2016), BR. 3, STR. 291-307

STOJČIĆ, N., BEČIĆ, M., VOJINIC,

THE IMPACT OF..

\section{CONCLUSION}

\section{REFERENCES}

ers in less innovation intensive regions who should develop measures for better exploitation of their regional innovation potential. Finally, the positive impact of GDP per capita level on innovation activity supports our expectations about the beneficial impact of a regional level of development on the potential for transformation of creative ideas into innovation output.

A higher prospect of growth depends on the ability of nations and regions to specialise themselves in the production of knowledge and technology intensive products. The underlying logic behind such reasoning is that innovations provide their owners with the ability to differentiate from their rivals and to accrue above-average returns on their activities. Immigration movements may influence labour force structure in many different ways that could promote the conceptualization, development and market success of new products and services. Contributions of a number of academic disciplines point out the positive impact of the heterogeneity of the population on the generation of new ideas, knowledge diffusion, entrepreneurship and economic growth.

In this paper, a novel approach is adopted in order to explore spatial effects of migration and innovation patterns in Croatian counties. This approach reveals some interesting patterns of the migration-innovation relationship. The analysis of migration patterns in Croatian counties indicates that regions with high innovation activity are also characterised by high immigration level. Furthermore, a higher intensity of innovation activities in a certain region facilitates the same activity in the neighbouring regions. The results obtained through the use of spatial econometric technique point out the positive between-regional effects of migration on innovation activities.

Research results highlight the necessity of expanding the analysis of this issue in order to broaden findings of the relationship between migration movements and innovations at the regional level. This research may be helpful to the Croatian policy makers who are searching for new policies to stimulate less innovative regions towards better utilisation of the regional potential.

Aghion, P., \& Howitt, P. (1992). A model of growth through creative destruction. Econometrica, 60(2), 323-351. doi:10.2307/2951599

Aghion, P., \& Howitt, P. (1998). Endogenous growth theory. Cambridge, Massachusetts: MIT Press.

Alesina, A., \& La Ferrara, E. (2005). Ethnic diversity and economic performance. Journal of Economic Literature, 43(3), 762-800. doi:10.1257/ 002205105774431243 
DRUŠ. ISTRAŽ. ZAGREB GOD. 25 (2016), BR. 3 STR. 291-307

STOJČIĆ, N., BEČIĆ, M., VOJINIĆ, P. THE IMPACT OF..
Anselin, L. (1996). The Moran Scatterplot as an ESDA tool to assess local instability in spatial association. In M. Fischer, H. Scholten, \& D. Unwin (Eds.), Spatial analytical perspectives on GIS (pp. 111-125). London: Taylor and Francis.

Arundel, A., \& Kabla, I. (1998). What percentage of innovations are patented? Empirical estimates for European firms. Research Policy, 27(2), 127-141. doi:10.1016/S0048-7333(98)00033-X

Baltagi, B. H., Egger, P., \& Pfaffermayr, M. (2007). Estimating models of complex FDI: Are there third-country effects? Journal of Econometrics, 140(1), 260-281. doi:10.1016/j.jeconom.2006.09.009

Bratti, M., \& Conti, C. (2013). Immigration, population diversity and innovation of Italian regions. Available at http://www.siecon.org/ online/wp-content/uploads/2013/09/Bratti-Conti.pdf

Breschi, S., Lissoni, F., \& Tarasconi, G. (2014). Inventor data for research on migration and innovation: A survey and a pilot, WIPO Economics \& Statistics Series, Economic Research Working Paper 17. Available at http://www.wipo.int/edocs/pubdocs/en/wipo_pub_econstat_wp_17.pdf

Brouwer, E., \& Kleinknecht, A. (1999). Innovative output and a firm's propensity to patent. An exploration of CIS micro data. Research Policy, 28(6), 615-624. doi:10.1016/s0048-7333(99)00003-7

Burridge, P. (1981). Testing for a common factor in a spatial autoregression model. Environment and Planning, 13(7), 795-800. doi:10. 1068/a130795

David, P. A. (1993). Intellectual property institutions and the Panda's thumb: Patents, copyrights, and trade secrets in economic theory and history. In M. B. Wallerstein, M-E. Mogee, \& R. A. Schoen (Eds.), Global dimensions of intellectual property rights in science and technology (pp. 19-29). Washington, D.C.: National Academies Press.

Elhorst, J. P. (2013). Spatial panel models. In M. M. Fischer, \& P. Nijkamp (Eds.), Handbook of regional science (pp. 1637-1652). Berlin: Springer-Verlag.

Faggian, A., \& McCann, P. (2006). Human capital flows and regional knowledge assets: A simultaneous equation approach. Oxford Economic Papers, 58(3), 475-500. doi:10.1093/oep/gpl010

Faggian, A., \& McCann, P. (2009). Human capital, graduate migration and innovation in British regions. Cambridge Journal of Economics, 33(2), 317-333. doi:10.1093/cje/ben042

Feldman, M. P., \& Florida, R. (1994). The geographic sources of innovation: Technological infrastructure and product innovation in the United States. Annals of the Association of American Geographers, 84(2), 210-229. doi:10.1111/j.1467-8306.1994.tb01735.x

Freeman, C., \& Soete, L. (1997). The economics of industrial innovation, 3. Ed. Milton Park, Routledge.

Fujita, M., Krugman, P., \& Venables, A. J. (1999). The spatial economy. Cambridge: MIT Press.

Fujita, M., \& Weber, S. (2004). Strategic immigration policies and welfare in heterogeneous countries, Fondazione Eni Enrico Mattei (FEEM), Working Paper, 2. 
DRUŠ. ISTRAŽ. ZAGREB GOD. 25 (2016), BR. 3, STR. 291-307

STOJČIĆ, N., BEČIĆ, M., VOJINIC, THE IMPACT OF.
Grossman, G., \& Helpman, E. (1994). Endogenous innovation in the theory of growth. The Journal of Economic Perspectives, 8(1), 23-44. doi:10.1257/jep.8.1.23

Hunt, J. (2009). Which immigrants are most innovative and entrepreneurial? Distinctions by entry. IZA Discussion Paper No. 4745.

Hunt, J., \& Gauthier-Loiselle, M. (2008). How much does immigration boost innovation? IZA Discussion Paper No. 3921.

Hunt, J., \& Gauthier-Loiselle, M. (2010). How much does immigration boost innovation? American Economic Journal: Macroeconomics, 2(2), 31-56. doi:10.1257/mac.2.2.31

Kemp, R. G. M., Folkeringa, M., de Jong, J. P. J., \& Wubben, E. F. M. (2003). Innovation and firm performance. scales research reports. Zoetermeer: EIM business and policy research. Available at http://www. ondernemerschap.panteia.nl/pdf-ez/h200207.pdf

Kerr, W. (2009). The agglomeration of US ethnic inventors, NBER Working Papers.

Krugman, P. (1991). Increasing returns and economic geography, Journal of Political Economy, 99(3), 483-499. doi:10.1086/ 261763

Le Sage, J. P. (1999). The theory and practice of spatial econometrics, Working Paper, University of Toledo, Department of Economics.

Maré, D. C., Fabling, R., \& Stillman, S. (2011). Immigration and innovation, Discussion paper series // Forschungsinstitut zur Zukunft der Arbeit No. 5686

Mazzolari, F., \& Neumark, D. (2009). Beyond wages: The effects of immigration on the scale and composition of output, NBER Working paper 14900, National Bureau of Economic Research, Cambridge Mass.

Miguelez, E., \& Fink, C. (2013). Measuring the international mobility of inventors: A new database. World Intellectual Property Organization Economics and Statistics Division. Available at http://www.wipo.int/ export/sites/www/econ_stat/en/economics/pdf/wp8.pdf

Niebuhr, A. (2010). Migration and innovation: Does cultural diversity matter for regional R\&D activity? Papers in Regional Science, 89(3), 563-585. doi:10.1111/j.1435-5957.2009.00271.x

Olejnik, A. (2008). Using the spatial autoregressively distributed lag model in assessing the regional convergence of per-capita income in the EU25. Papers in Regional Science, 87(3), 371-384. doi:10.1111/j.14355957.2008.00190.x

Ottaviano, G. I. P., \& Peri, G. (2006). The economic value of cultural diversity: Evidence from US cities. Journal of Economic Geography, 6(1), 9-44. doi:10.1093/jeg/lbi002

Ozgen, C., Nijkamp, P., \& Poot, J. (2011). Immigration and innovation in European regions, Tinbergen Institute Discussion Paper, No. 11-112/3

Partridge, J., \& Furtan, H. (2008). Increasing Canada's international competitiveness: Is there a link between skilled immigrants and innovation? American Agricultural Economics Association Annual Meeting, Orlando FL, July 27-29.

Poot, J., Waldorf, B., \& van Wissen, L. (2008). Migration and human capital. Cheltenham UK: Edward Elgar. 
DRUŠ. ISTRAŽ. ZAGREB GOD. 25 (2016), BR. 3, STR. 291-307

STOJČIĆ, N., BEČIĆ, M., VOJINIĆ, P.

THE IMPACT OF...
Romer, P. M. (1986). Increasing returns and long-run growth. Journal of Political Economy, 94(5), 1002-1037. doi:10.1086/261420

Romer, P. (1990). Endogenous technological change. Journal of Political Economy, 98(5), 71-102. doi:10.1086/261725

Saxenian, A. (1999). Silicon Valley's new immigrant entrepreneurs. San Francisco: Public Policy Institute of California.

Schumpeter, J. A. (1942). Capitalism, socialism and democracy. New York: Harper \& Row.

Solow, R. M. (1956). A contribution to the theory of economic growth. The Quarterly Journal of Economics, 70(1), 65-94. doi:10. 2307/1884513

Stephan, P. E., \& Levin, S. G. (2001). Exceptional contributions to US science by the foreign-born and foreign-educated. Population Research and Policy Review, 20(1), 59-79. doi:10.1023/A:1010682017950

Wadhwa, V., Saxenian, A., Rissing, B., \& Gereffi, G. (2008). Skilled immigration and economic growth. Applied Research in Economic Development, 5(1), 6-13.

\section{Utjecaj migracijskih kretanja na inovacijske aktivnosti u hrvatskim županijama}

Nebojša STOJČıĆ, Marija BEČIĆ, Perica VOJINIĆ Sveučilište u Dubrovniku, Dubrovnik

Inovacijske aktivnosti jedan su od najvažnijih pokretača gospodarskog rasta. Među činiteljima koji utječu na razvoj inovacijske aktivnosti osobito važno mjesto pripada sociološkoj i kulturološkoj raznolikosti stanovništva nekoga područja. Doprinosi unutar više znanstvenih disciplina upućuju na pozitivan utjecaj populacijske raznolikosti na stvaranje novih ideja, difuziju znanja, razvoj poduzetništva i gospodarski rast. Unatoč navedenom, veza između migracija $\mathrm{i}$ inovacijske aktivnosti na regionalnoj razini relativno je neistraženo područje i u domaćoj i u svjetskoj literaturi. To osobito dolazi do izražaja kada se govori o prostornim učincima migracija na inovacije koje nisu bile predmet dosadašnjih istraživanja. Cili je ovog rada istražiti prostorni utjecaj migracija na inovacijsku aktivnost hrvatskih županija od 2005. do 2013. Rezultati dobiveni primienom ekonometrijske metode prostornoga Durbin panela upućuju na pozitivan utjecaj međunarodnih migracija na inovacijsku aktivnost. Međužupanijske migracije imaju negativan utjecaj unutar regija dok je interregionalni utjecaj ovog obrasca migracija pozitivan. Porast inovacijske aktivnosti pojedinih regija negativno utječe na istu aktivnost susjednih regija.

Ključne riječi: imigracija, inovacije, regionalna analiza 